\title{
REPRODUCTIVE CHARACTERISTICS AND HABITAT SELECTION OF CARABUS ULRICHII (COLEOPTERA, CARABIDAE) IN WOODLAND HABITATS IN HUNGARY
}

\author{
Ferenc Kádár ${ }^{1 *}$, Rita Andorkó2* and Zoltán Elek ${ }^{3}$ \\ ${ }^{1}$ Centre for Agricultural Research, Plant Protection Institute, Hungarian Academy of Sciences, \\ H-1022 Budapest, Herman Ottó út. 15, Hungary; E-mail: aptinus@freemail.hu \\ ${ }^{2}$ Department of Systematic Zoology and Ecology, Faculty of Sciences, Institute of Biology \\ Eötvös Loránd University, H-1117 Budapest, Pázmány Péter sétány 1/C, Hungary \\ E-mail: andorko.rita@gmail.com \\ ${ }^{3}$ MTA-ELTE-MTM Ecology Research Group, Institute of Biology, Eötvös Loránd University \\ H-1117 Budapest, Pázmány Péter sétány 1/C, Hungary; E-mail: elek.zoltan@okologia.mta.hu
}

The distribution, seasonality and reproductive characteristics of Carabus ulrichii (Coleoptera, Carabidae) were studied in woodland habitats in Hungary. We sampled a beech forest, an oak forest and the adjacent transition zone using pitfall traps, in the Pilis Biosphere Reserve in 2005 and 2006. Generalised linear models were used to explore the impacts of the habitat quality and seasonality on the distribution of this species. We found that the light intensity model explained best the species' activity density pattern, suggesting preference for open oak forest. We also found that the mandible wear was not a good estimator of age in C. ulrichii, but ovarial condition could be used to assess reproductive status. The seasonal activity and life history patterns were similar in the three different habitats for both sexes. Although differences in the total activity density of the species were found, there were no differences either in the seasonal activity patterns, or in the age-composition, or in the reproductive characteristics of $C$. ulrichii among the studied habitats. C. ulrichii beetles reproduced only once per season in the studied forested habitats.

Keywords: Carabus ulrichii, forest habitats, seasonal activity, reproduction, age-composition.

\section{INTRODUCTION}

Ground beetles are one of the most species-rich families of Coleoptera, forming a significant part of the ground surface active fauna in most of their area of occurrence and also are among the best known insect taxa in the northern hemisphere (Lövei \& Sunderland 1996). Ground beetles show clear associations with environmental parameters such as soil type and vegetation cover, thus good indicators of environmental change (e.g. Thiele 1977). Furthermore, carabids are relatively long-living animals allowing useful sampling to be carried out by relative easy-to-use pitfall traps (Lindroth 1974) for the whole growing season in Europe. It provides a good basis for the estimation of the seasonality for these insects. Seasonality is an important part of the insect ecology since it could provide a snapshot about the viability of

The two authors equally contributed to this paper.

Hungarian Natural History Museum, Budapest 
the population; seasonality should preferably described quantitatively as in some recent publications (e.g. FAzeKas et al. 1997, PoKLuda et al. 2012, BÉrCES \& ELEK 2013). Environmental change related concerns make it relevant to have a more precise understanding of the spatial and temporal variation in ground beetles. Given that several species are protected, such information would be useful to harmonise conservation efforts during habitat management operations, like the use of chemicals in agricultural lands, forest management, etc., to minimise risk to non-target ground beetles.

In 1982, within the framework of the Man and the Biosphere Programme $(\mathrm{MAB})$ a long-term monitoring project was started in the Pilis Biosphere Reserve (PBR), a woodland region in Hungary, including several projects aimed at arthropods (BERCZIK 1984). The first results on carabids were published by KÁDÁR and SzÉL (1999) concerning on the ground beetle assemblages from 15 topographically different sites of the PBR. During our research, we studied two adjacent forest fragments and the transition zone within these in the Simon Valley, Pilis Mountains, within the territory of the above mentioned MAB reference site (ANDORKó \& KÁDÁR 2006). For further assessment of the seasonality and reproduction we studied the large carabid beetle, Carabus ulrichii Germar, 1824, which is a eurytopic species, but it occurs more frequently in hills and forests in Hungary. This species is also widely distributed; in the riverine hard-wood (oak-elm-ash) forests it can be frequent or common in Hungary (SzÉL et al. 2007). The conservation status of this species is sparsely estimated in Europe; it is noted on the Red List in Northern Europe as a declining or endangered species (Turin et al. 2003). Consequently, knowledge on the main life-history characteristics (inc. seasonality, and reproduction) would be useful for future conservation efforts.

In this paper, we present the results of the assessment of the habitat selection, seasonality, age-composition and reproductive characteristics of this large forest carabid species considering the effects of environment conditions that might influence the distribution of this species. We summarized our approach in the following questions:

1. Are there any differences in the activity density and seasonal activity patterns among the habitat types?

2. What is/are the most relevant environmental variable(s) that might influence the distribution of this species?

3. Are there any differences in their age-composition and reproduction characteristics among the habitat types?

\section{MATERIAL AND METHODS}

Study area - The study area was located in the Pilis Biosphere Reserve, in the Pilis Mountains, $50 \mathrm{~km}$ from North of Budapest $\left(47^{\circ} 59^{\prime} \mathrm{N}, 18^{\circ} 54^{\prime} \mathrm{E}\right.$, mean altitude $267 \mathrm{~m}$ a.s.l.). 
Three forested habitats were sampled during the study: (1) Beech forest (Melittio-Fagetum) where the dominant trees were Fagus silvatica, and Carpinus betulus in the canopy, but Acer pseudoplatanus was also present. In the sparse shrub layer, Ribes uva-crispa and Daphne mezerum were present. The herb layer was seasonally dense with Anemone nemorosa and Corydalis cava and Impatiens noli-tangere. (2) A transition zone intersected the beech forest from the adjacent oak forest. This zone was about $30 \mathrm{~m}$ wide dominated by Asarum europaeum, Urtica dioica, Fragaria vesca and nitrophilous weeds. The canopy layer was moderately open. (3) An oak forest (Querco petrae-Carpinetum) was also sampled. In the canopy, Quercus petrea and Carpinus betulus were present. The shrub layer was entirely missing, while the herb layer was dominated by the seasonally dense plants: Corydalis cava and Anemone ranunculoides. The studied forest patches were similar in their size (ca 0.5 ha each). These forest patches were isolated by forest roads and paths from the adjacent forest stands.

Sampling design - Carabids were sampled by pitfall traps (plastic cups of $80 \mathrm{~mm}$ diameter, $300 \mathrm{ml}$ volume, containing $4 \%$ formaldehyde as a killing and preserving agent, metal cover above the traps). The traps were emptied weekly from the end of April to the beginning of October during two consecutive years, in 2005 and in 2006. Five pitfall traps were installed in each habitat, the intertrap distance was $5 \mathrm{~m}$, and the traps were arranged in a row. For appropriate sampling of the core habitats the distance from the edge was considered at least 20 $\mathrm{m}$ in the beech and oak forests. In order to consider the effects of environmental differences among the studied habitats, we measured the environmental variables, which may influence on the carabid distribution (sensu ButTERFIELD et al.1995): relative air humidity; light intensity, ground and air temperature. These variables were measured in a $2 \mathrm{~m}$ radius around the pitfall trap in a typical day, each habitat, every season with whisker sensors for Hobo instrument (Hobo datalogger/BHW, Onset Computer Corporation, Bourne, MA, USA).

Age determination and reproduction characteristics - Beetles caught were sexed and aged. Ageing was based on the extent of bristle and on mandible wear, elytra hardness and coloration (VAN DijK 1972, 1979): individuals with soft or flexible elytra, sharp mandibles, long and intact bristles were considered young. Individuals with hard and fully coloured elytra, severely worn mandibles and bristles were classified as old. Mature middle-aged beetles had transitional characteristics, with some hardened cuticular parts, and little wear on mandibles or bristles.

Females were dissected in order to determine the developmental stage of their ovaries and the number of egg, following the method of VAN DijK $(1972,1979)$, Wallin (1989) and Diefenbach et al. (1991). We defined three categories (Andorkó et al. 2005): (1) immature beetles without eggs in ovaries, having compact, small, long ovaries, narrow and twice as long common oviduct as the lateral oviducts (pre-reproductive stage); (2) gravid beetles with eggs of different stages of maturation present in the ovaries, lateral oviducts have longer diameter (reproductive stage); (3) spent beetles with lateral oviducts large, ovaries less compact than those of an immature female, beetles that passed at least one reproductive season (post-reproductive stage).

Species-habitat models - Generalized linear models based on the Gaussian distribution were used to study the relationship between single environmental variables and total activity density. In these models the log-transformed species activity density was the response variable and two explanatory variables were included, the habitat type and one of the studied environmental variables: ground temperature, air temperature, relative air humidity and light intensity. Based on this model arrangement, the effect of the habitat type was considered according to the environmental variable included.

1. Null model: no other (explanatory) variable than the intercept;

2. Ground-temperature model: continuous, ground temperature $\left({ }^{\circ} \mathrm{C}\right)$; 


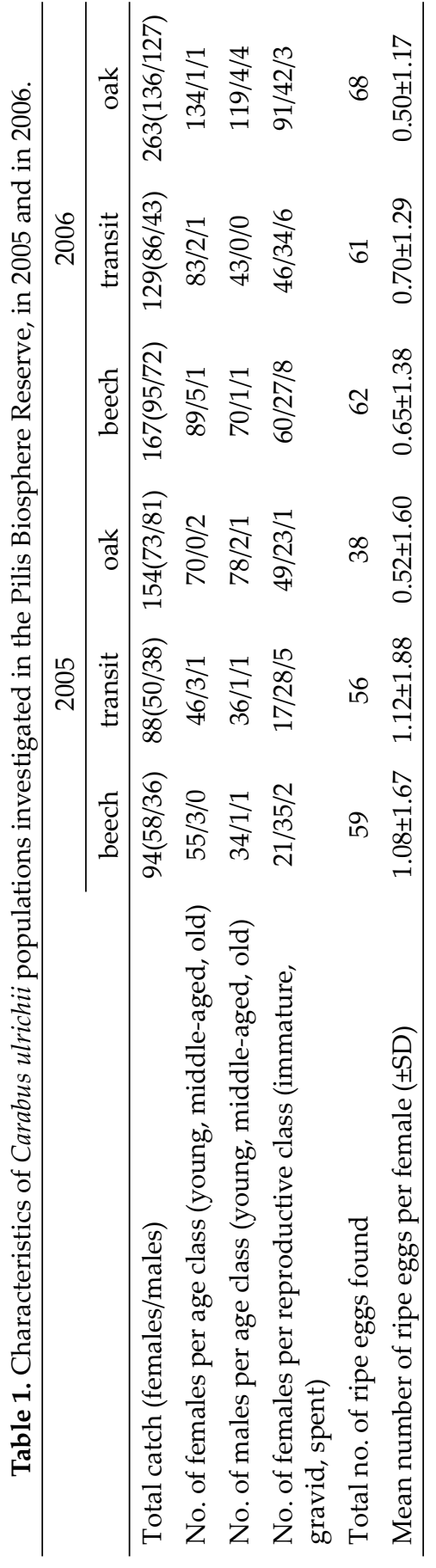

3. Air-temperature model: continuous, temperature (measured $1 \mathrm{~m}$ above ground) $\left({ }^{\circ} \mathrm{C}\right)$;

4. Relative humidity model: continuous, the amount of water vapour in the air expressed as percentage;

5. Light model: continuous, expressed in lux; as the measurement of the light intensity.

The same above mentioned approach was also applied to study the main effects of seasonality on the total activity density, the activity density according to the life-history traits and the reproductive estimator of the studied species. In the models the activity density (per trap) according to sex, the age composition, the developmental stages of the ovaries and the number of eggs were the response variables, while the habitat type, seasonality and year included as explanatory variables. We named these models by their response variables: 1 . -abundance; 2. -young-male; 3. -middle-aged-male; 4. -old-male; 5.-young-female; 6. -middle-agedfemale; 7. -old-female; 8.-immature; 9. -gravid; 10. -spent; 11.-eggs.

Data analysis - We used a model selection information criterion AIC (AKAIKE 1974) to rank the models above in terms of their ability to explain species activity densities while accounting for the number of parameters estimated (Burnham \& Anderson 2002). In this way, a "best approximating" model was selected as the most parsimonious explanation of the data. In the most parsimonious model(s), the differences among the levels of the tested factor (habitat type) were revealed by multiple comparisons (with Tukey computed contrast matrices for several multiple comparison procedures). The responses were also checked by Cleveland's dot plots as a graphical interpretation (Cleveland 1985). The analyses were carried out in R 2.8.1 (R Development Core Team 2008) using packages stat and multcomp.

\section{RESULTS}

\section{Age composition}

In both years young individuals gave the most of the catches which were the highest in the oak forest with no major differenc- 
es by the sexes (Figs $1 \& 2$, Table 1). Only a few middle-aged and old beetles were found in any of the three habitats. Overall, the activity density of young males's activity density was the highest in the oak forest in both years.

\section{Reproductive characteristics}

We found immature beetles in every year (Fig. 3). In 2005, in all habitats the activity density peak of the immature females occurred at the end of August and that of the mature females at the end of May. We found a few spent females at the beginning of the season. During the following year we captured the highest number of immature females in all habitats at the beginning of August, the mature females at the beginning of May. Few spent females were also present in the samples throughout the season. The activity density of females with immature ovaries was the highest in the oak forest (Table 1). The size of ripe eggs of C. ulrichii is relatively large, 5.1-6.6 mm (SCHERney 1959).

Females had a maximum of 7 ripe eggs in their ovaries, most frequently only 2 . The number of ripe eggs found in the ovaries did not show significant differences among the habitats (Table 1). The number of the maximum ripe eggs per females was 0.9 in 2005 and 0.65 in 2006. The number of the maximum ripe eggs per the number of gravid females was 1.82 in 2005 and 1.85 in 2006.

\section{Species - habitat and seasonality modelling}

The light intensity model explained best the distribution of C. ulrichii (Table 2), occurring in the highest number in the oak forest. We captured $895 \mathrm{C}$. ulrichii individuals, 498 females and 397 males during the two years (Table 1). The entire activity period of the two years of sampling lasted from the end of April until the end of September with two activity peaks (Fig. 4). In 2005, the first slight activity peak in all the three habitats occurred at the end of May and the second peak was at the end of August. The activity profile was similar in 2006. These patterns were revealed by the results of seasonality models (Table 2).

\section{DISCUSSION}

In Hungary, C. ulrichii seems to have similar activity patterns as to the published ones (TuRIN et al. 2003), however we revealed some differences with regard to the reproduction characteristics. The results of species-habitat modelling showed that the species select the habitats according to the light intensity. Thus, it occurred in the highest number in the open oak forest, but the species could use all the habitat types simultaneously. Even though we captured more individuals in the oak forest than in the other habitat types, there 
were no differences either in the seasonal activity patterns, age-composition, or in the reproductive characteristics of $C$. ulrichii among the studied habitat types.

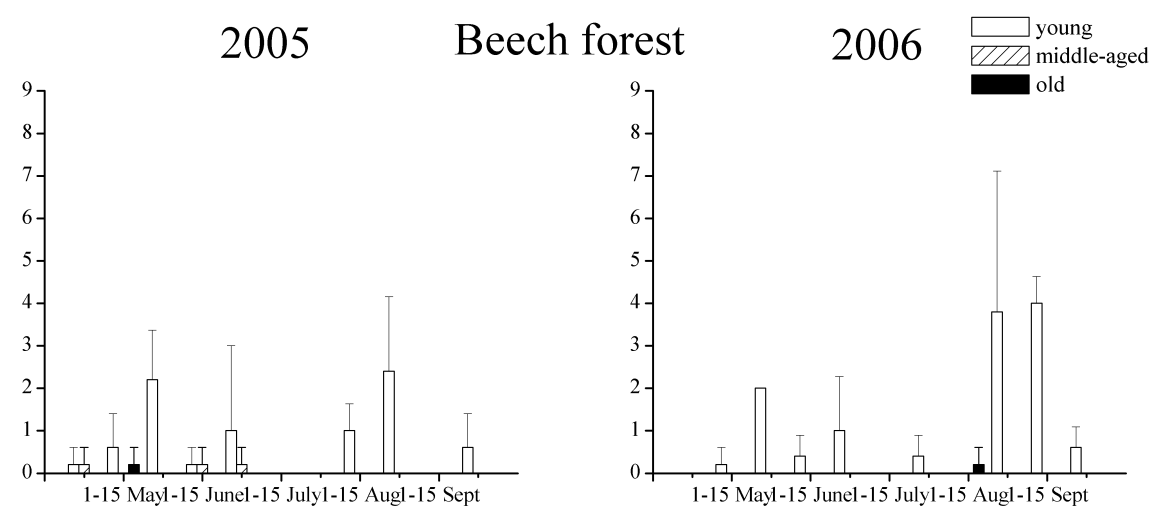

\section{Transition zone}
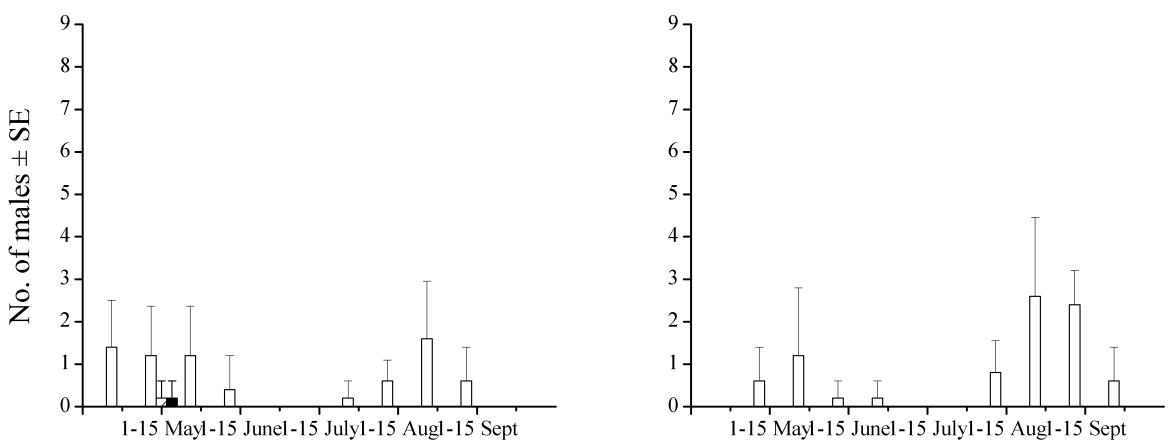

\section{Oak forest}
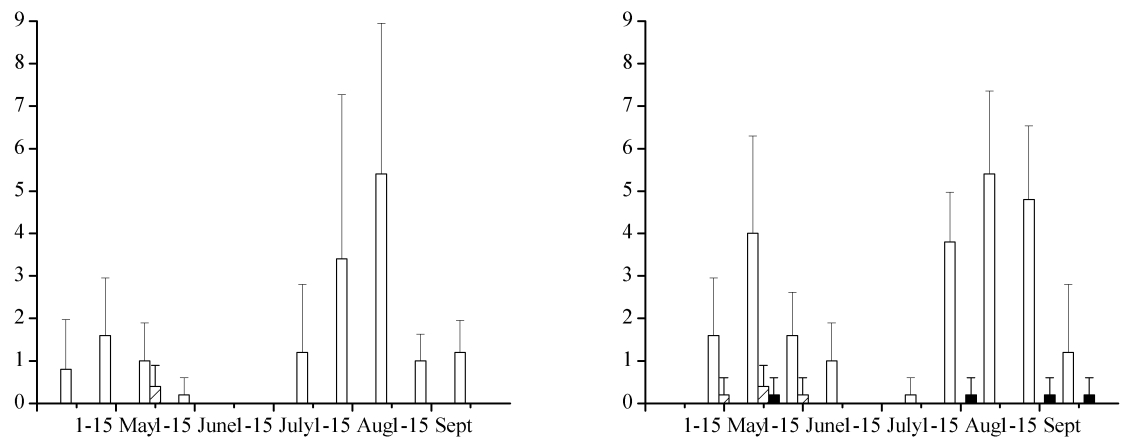

Time (fortnights)

Fig. 1. Different age-categories of C. ulrichii males in the three habitats in the PBR, in 2005 and 2006 
C. ulrichii occurs in wet, shady and also in dry, light forests of Slovakia (KLEINERT 1983), also occurs in oak forests in plain part of Croatia (VujCicKarlo \& Durbesic 2004). The typical habitat of this species in Hungary is the riverine oak-elm-ash forests in the plains (SzÉL et al. 2007). In our study the species distinguished the habitats, i.e. occurring in higher number in the open

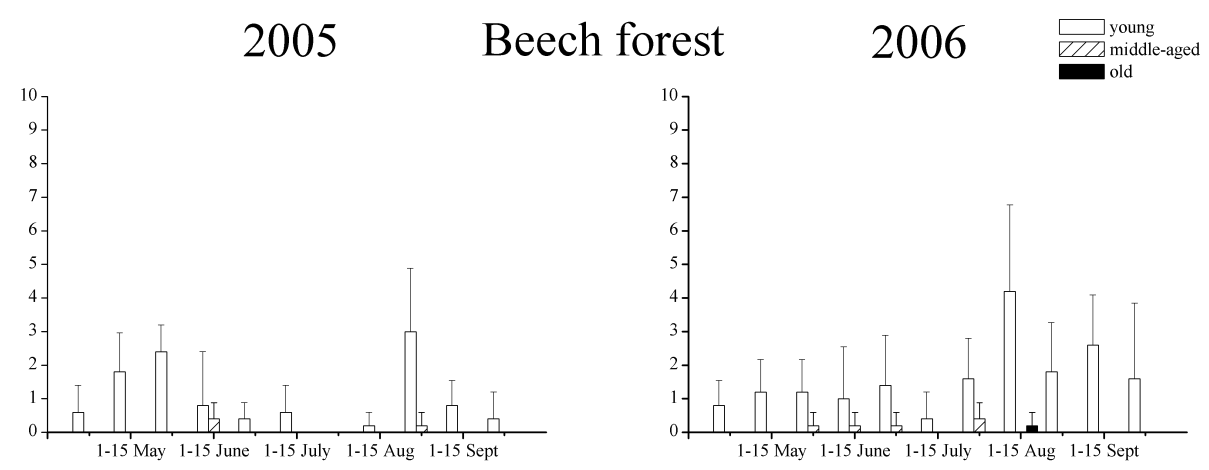

\section{Transition zone}
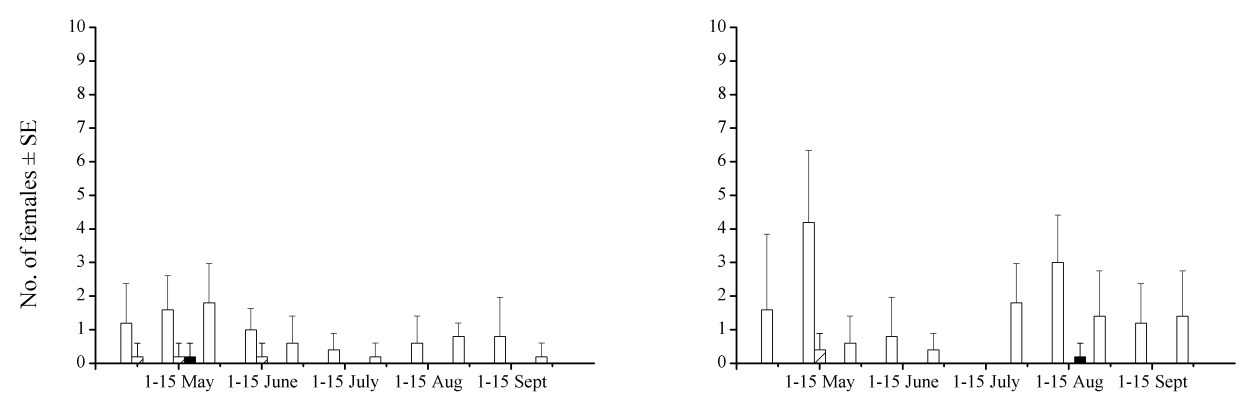

Oak forest
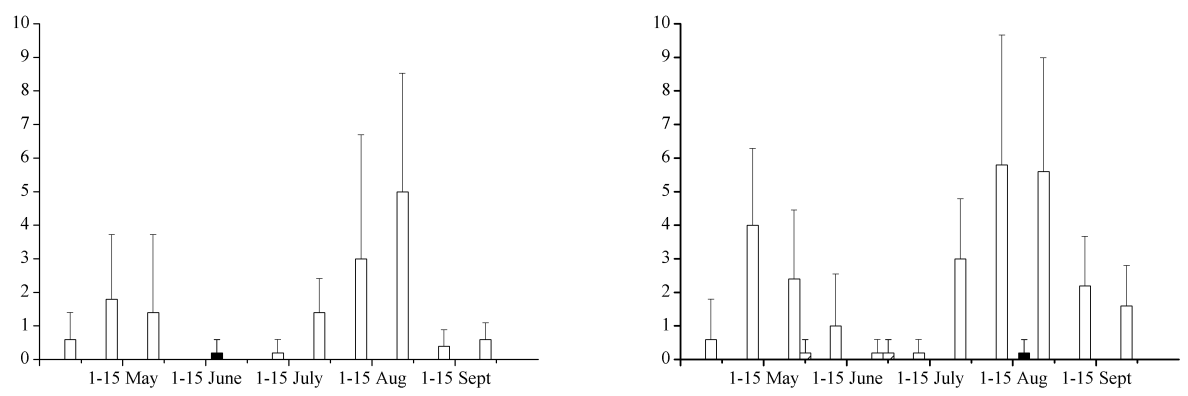

Time (fortnights)

Fig. 2. Different age-categories of C. ulrichii females in the three habitats in the PBR, in 2005 and 2006 
oak forest, but also used the other habitats. C. ulrichii is a typical spring breeder species with summer larvae (Turin et al. 2003). The young adults appear during August, than they are active until hibernation. The beetles appearing in spring reproduce until early summer, after which most of the beetles die. The
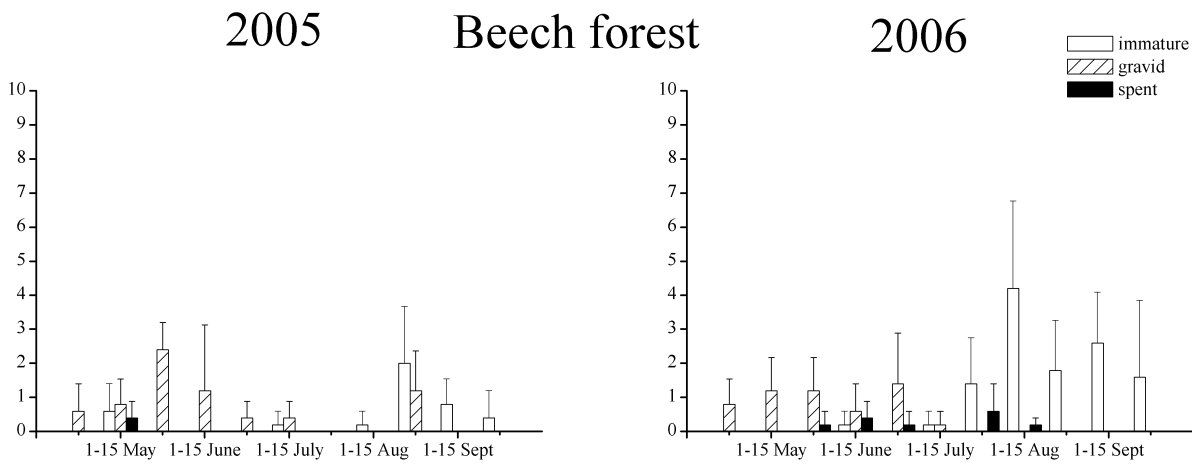

\section{Transition zone}
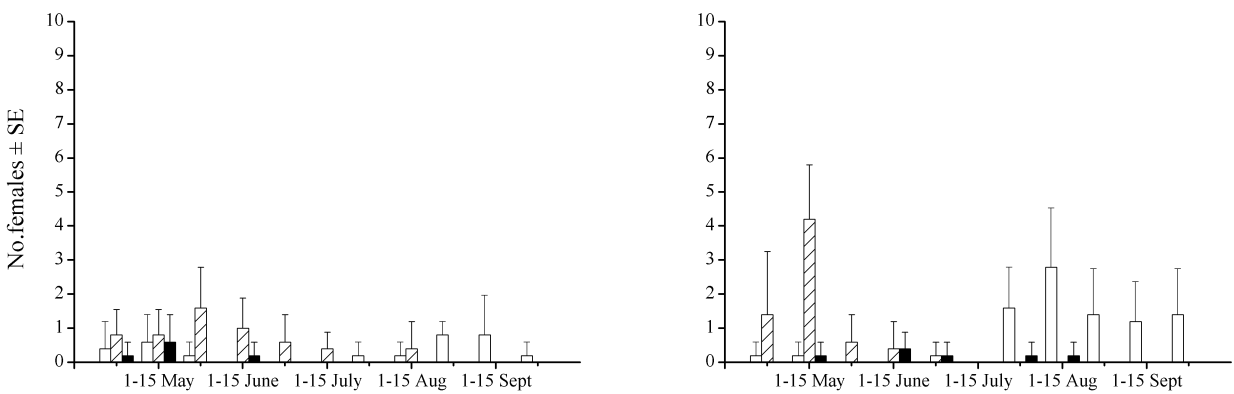

\section{Oak forest}
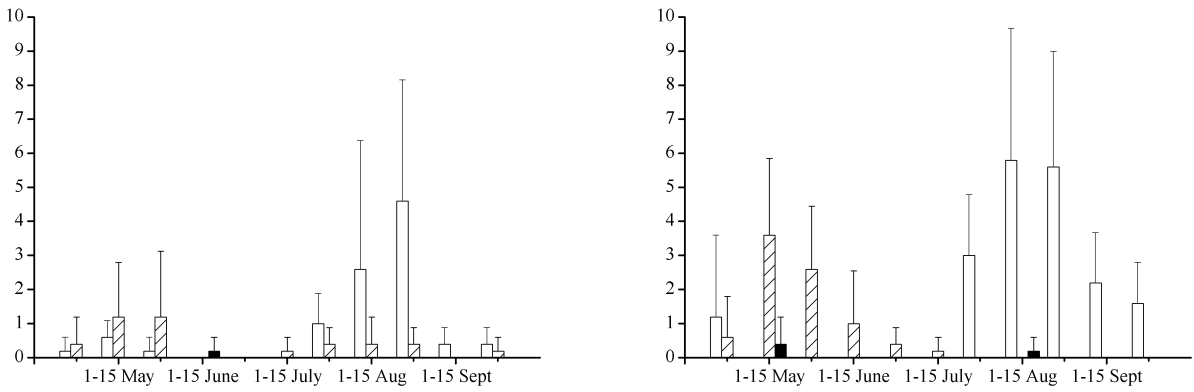

Time (fortnights)

Fig. 3. The mean number of $C$. ulrichii females in each developmental stage in the three habitats in the PBR, in 2005 and 2006 
Table 2. Results of the models in the studied sites of C. ulrichii in the Pilis Biosphere Reserve, in 2005 and 2006. Model selection was based on Akaike Information Criteria (АкаIкE 1974). In the columns the average predicted values (beta) indicated as the descriptor of the magnitude of the effect.

\begin{tabular}{lcccc}
\hline & \multicolumn{4}{c}{ Average predicted values with S.D. } \\
\hline Model's name & beech & transit & oak & comparison \\
\hline Species-habitat models & & & & \\
light-intensity model & $3.94 \pm 0.22$ & $3.76 \pm 0.17$ & $4.39 \pm 0.08$ & $\mathrm{O}>\mathrm{B}^{* *} ; \mathrm{O}>\mathrm{T}^{* * *}$ \\
\hline Seasonality models & & & & \\
1-overall abundance & $0.9 \pm 0.5$ & $0.85 \pm 0.5$ & $1.15 \pm 0.5$ & $\mathrm{O}>\mathrm{B}^{* *} ; \mathrm{O}>\mathrm{T}^{* *}$ \\
2-young-male & $0.44 \pm 0.38$ & $0.38 \pm 0.38$ & $0.73 \pm 0.38$ & $\mathrm{O}>\mathrm{B}^{* * *} ; \mathrm{O}>\mathrm{T}^{* * *}$ \\
3-middle-aged-male & $0.01 \pm 0.02$ & $0.006 \pm 0.02$ & $0.03 \pm 0.02$ & $\mathrm{NS}$ \\
4-old-male & $0.01 \pm 0.01$ & $0.006 \pm 0.01$ & $0.02 \pm 0.01$ & $\mathrm{NS}$ \\
5-young-female & $0.63 \pm 0.33$ & $0.58 \pm 0.33$ & $0.72 \pm 0.33$ & $\mathrm{NS}$ \\
6-middle-aged-female & $0.05 \pm 0.03$ & $0.03 \pm 0.03$ & $0.01 \pm 0.03$ & $\mathrm{NS}$ \\
7-old-female & $0.006 \pm 0.02$ & $0.01 \pm 0.02$ & $0.01 \pm 0.02$ & $\mathrm{NS}$ \\
8-immature & $0.34 \pm 0.38$ & $0.29 \pm 0.38$ & $0.48 \pm 0.38$ & $\mathrm{O}>\mathrm{T}^{* *}$ \\
9-gravid & $0.3 \pm 0.28$ & $0.28 \pm 0.28$ & $0.27 \pm 0.28$ & $\mathrm{NS}$ \\
10-spent & $0.06 \pm 0.05$ & $0.06 \pm 0.05$ & $0.02 \pm 0.05$ & $\mathrm{NS}$ \\
11-eggs & $0.4 \pm 0.43$ & $0.37 \pm 0.43$ & $0.29 \pm 0.43$ & $\mathrm{NS}$ \\
\hline
\end{tabular}

Legends: ${ }^{*} \mathrm{p}<0.05 ;{ }^{* *} \mathrm{p}<0.01 ;{ }^{* * *} \mathrm{p}<0.001$. Beech, $\mathrm{B}=$ beech forest; transit, $\mathrm{T}=$ transition zone; oak, $\mathrm{O}=$ oak forest.

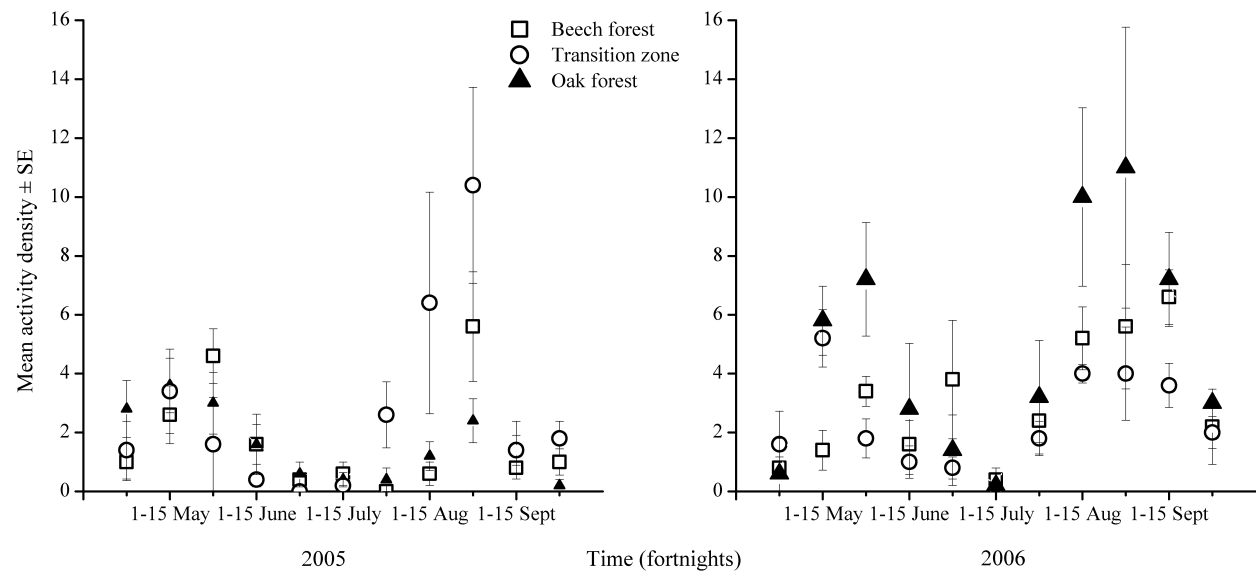

Fig. 4. Seasonal activity of C. ulrichii individuals in the three habitats in the PBR, in 2005 and 2006 
new generation appears in August, becoming fully active, although it only reproduces subsequent to hibernation. C. problematicus captured from different altitudes have different life strategies, low altitude beetles are predominantly annual and high altitude beetles are predominantly biannual (SPARKs et al. 1995). We found no differences between the seasonal and reproductive activity patterns of the beetles among the three different habitat types. Perhaps such differences as found in C. problematicus exist at a larger scale.

Summer larvae were followed by immature females which appeared in August indicating the second peak in activity. The peak in the number of mature females indicated the reproductive peak in early summer. Afterwards, the small number of individuals indicated that the beetles had died after the reproductive period and we found only a few numbers of spent females. There were no eggs in those individuals. The reproductive (May) and the activity period (August) of this species do not overlap. Based on these clues we suggest that $C$. ulrichii beetles reproduce only once during one season in their life-time in forested habitats in Hungary.

According to ANDORKó and KÁDÁr (2006), Carabus scheidleri is one of the most abundant species collected from the same site in 1986, while in the following years, this species was hardly found. Although C. ulrichii was hardly present in the traps in the 1980s, it was the fourth most abundant ground beetle in 1993 with more than 200 individuals and the second one in 1994. The decreasing number of $C$. scheidleri showed that this species preferred the humanmodified, disturbed habitats (ANDORKó et al. 2005), and as the canopy closed and the human disturbance decreased, the forest-specific $C$. ulrichii appeared. C. scheidleri assures the persistence of the population at different levels and in different ways (e.g. the presence of old beetles in the reproduction, several reproductive periods in the same season, overlapping of different generations, high number of ripe eggs per female) (Andorkó \& Kádár 2009). However, C. ulrichii preferring the stable, deciduous forests where no such large habitat alterations occur, the population can survive with the spring breeder strategy, with one reproductive period, adult hibernation, and low numbers of ripe eggs per female.

Based on our results, we propose that C. ulrichii has a functionally bimodal activity pattern. The early season activity peak reflects the high activity of females, because of the reproductive period, while the late activity peak is characterised by the high activity of newly emerged, foraging adults. This pattern was similar in the two years, and in all studied habitats, therefore the species has constant activity pattern in the studied forest habitats. However, this pattern can alter locally such as in the study of VujCic-Karlo and Durbensic (2004). Similarly to this species, large carabids in general with constant seasonality demonstrated less spatio-temporal variation in their activity density (KÁDÁr et al. 2015). Large species are often long-lived, have low densities and 
probably low reproductive capacity which dampens their year-to-year population fluctuations (LufF 1982, Lövei \& SUNDERLAND 1996). We also found that this species can reproduce only once per season with relatively low fecundity rate. These attributes make this species more vulnerable similarly to the large carabids, because their potential to respond to unfavourable or extreme environmental variation (i.e. fragmentation) may be limited.

Acknowledgements - We thank the Middle-Danube-Valley Environmental, Nature and Water Inspectorate to approve the permission for the investigations. We thank the two anonymous reviewers for their constructive help in the revision.

\section{REFERENCES}

AкаIкe, H. (1974): A new look at the statistical model identification. - IEEE Transactions on Automatic Control 19: 716-722. https://doi.org/10.1109/TAC.1974.1100705

Andorkó, R., KÁdÁr, F. \& Szekeres, D. (2005): Reproductive characteristics of Carabus scheidleri (Coleoptera: Carabidae) in Hungary. - DIAS Report 114: 9-16.

Andorkó, R. \& KÁdÁr, F. (2006): Carabid beetle (Coleoptera: Carabidae) communities in a woodland habitat in Hungary. - Entomologica Fennica 17: 221-228.

Andorkó, R. \& Kádár, F. (2009): Life-history characteristics of the ground beetle Carabus scheidleri (Coleoptera, Carabidae) in Hungary. - Acta Zoologica Academiae Scientiarum Hungaricae 55: 45-56.

Berczik, A. (1984): A Pilis Bioszféra Rezervátum kutatási programja. (The research programme of the Pilis Biosphere Reserve). - Állattani Közlemények 71: 14-16.

BÉrCES, S. \& ELEK, Z. (2013): Overlapping generations can balance the fluctuations in the activity patterns of an endangered ground beetle species: long-term monitoring of Carabus hungaricus in Hungary. - Insect Conservation and Diversity 6(3): 290-299.

Burnham, K. P. \& Anderson, D. R. (2002): Model selection and multimodel inference: a practical information theoretic approach. - Springer-Verlag, New York, USA, 488 pp.

Butterfield, J., Luff, M. L., Baines, M. \& Eyre, M. D. (1995): Carabid beetle communities as indicators of conservational potential in upland forests. - Forest Ecology and Management 79: 63-77. https://doi.org/10.1016/0378-1127(95)03620-2

Cleveland, W. S. (1985): The elements of graphing data. - Wadsworth, Monterey, $324 \mathrm{pp}$.

Diefenbach, L. M. G., Aner, U. \& Becker, M. (1991): The internal reproductive organs and physiological age-grading in Neotropical carabids: II. Parhypates (Paranortes) cordicollis (Dejean, 1828) (Coleoptera: Carabidae: Pterostichini). - Revista Brasileira de Biologia 51: 169-178.

Fazekas, J., KádÁr, F., SÁrospataki, M. \& Lövei, G. L. (1997): Seasonal activity, age structure and egg production of the ground beetle Anisodactylus signatus (Coleoptera: Carabidae) in Hungary. - European Journal of Entomology 94: 473-484.

Lövei, G. L. \& Sunderland, K. D. (1996): Ecology and behaviour of ground beetles (Coleoptera, Carabidae). - Annual Review of Entomology 41: 231-256. https://doi.org/10.1146/ annurev.en.41.010196.001311

Lindroth, C. H. (1974) Handbooks for the identification of the British insects. Coleoptera, Carabidae. - Royal Entomological Society of London, $149 \mathrm{pp}$. 
LufF, M. L. (1982): Population dynamics of Carabidae. - Annals of Applied Biology 101: 164-170.

KádÁr, F., FAZeKas, J., SÁrospataki, M. \& Lövei, G. L. (2015): Seasonal dynamics, age structure and reproduction of four Carabus species (Coleoptera, Carabidae) living in forested landscapes in Hungary. - Acta Zoologica Academiae Scientiarum Hungaricae 61: 57-72. https://doi.org/10.17109/AZH.61.1.57.2015

KÁDÁR, F. \& SzÉL, GY. (1999): Species composition and occurrence of ground beetles (Coleoptera, Carabidae) in the Pilis Biosphere Reserve, Hungary: a pitfall trap study. Folia entomologica hungarica 60: 205-212.

KLeinert, J. (1983): Ground beetles (Coleoptera, Carabidae) in selected habitats of lowland in southeastern Slovakia. - Biologia 38(10): 981-989.

Pokluda, P., Hauck, D. \& Cizek, L. S. (2012): Importance of marginal habitats for grassland diversity: fallows and overgrown tall-grass steppe as key habitats of endangered ground-beetle Carabus hungaricus. - Insect Conservation and Diversity 5: 27-36. https://doi.org/10.1111/j.1752-4598.2011.00146.x

R Development Core Team (2008): R: A language and environment for statistical computing. - R Foundation for Statistical Computing, Vienna, http://www.R-project.org.

SCHerney, F. (1959): Unsere Laufkäfer, ihre Biologie und wirtschaftliche Bedeutung. Die neue Brehm-Bücherei, 245. Heft. - A. Ziemsen Verlag, Wittenberg Lutherstadt, 79 pp.

Sparks, T. H., Buse, A. \& Gadsden, R. J. (1995): Life strategies of Carabus problematicus (Coleoptera, Carabidae) at different altitudes on Snowdon, north Wales. - Journal of Zoology 236: 1-10. https://doi.org/10.1111/j.1469-7998.1995.tb01779.x

Szél, Gy., Retezár, I., Bérces, S., Fülöp, D., Szabó, K. \& Pénzes, Zs. (2007): Magyarország futrinkái. [The Carabus species of Hungary (Coleoptera: Carabidae).] Pp. 81-106. In: Forró, L. \& MahunKa, S. (eds): A Kárpát-medence állatvilágának kialakulása. [The origin of the fauna of the Carpathian Basin.] Magyar Természettudományi Múzeum, Budapest. [in Hungarian]

Thiele, H. U. (1977): Carabid beetles in their environments, a study on habitat selection by adaptations in physiology and behaviour. Zoophysiology and ecology Ser. 10. - Springer Verlag, Berlin, 369 pp.

Turin, H., Penev, L. \& Casale, A. (2003): The genus Carabus L. in Europe. A synthesis. - Pensoft Publisher, Sofia-Moscow-Leiden, 536 pp.

VAN DijK, TH. (1972): The significance of the diversity in age composition of Calathus melanocephalus L. (Coleoptera, Carabidae) in space and time at Schiermonnikoog. Oecologia 10: 111-136. https://doi.org/10.1007/BF00347984

VAN DiJк, Tн. (1979): On the relationship between reproduction, age and survival in two carabid beetles: Calathus melanocephalus L. and Pterostichus coerulescens L. (Coleoptera, Carabidae). - Oecologia 40: 63-80. https://doi.org/10.1007/BF00388811

Vujcic-Karlo, S. \& Durbesic, P. (2004): Ground beetle (Coleoptera: Carabidae) fauna of two oak woods with two different water balances. - Acta entomologica slovenica 12: 139-150.

Wallin, H. (1989): The influence of different age classes on the seasonal activity and reproduction of four medium-sized carabid species inhabiting cereal fields. - Holarctic Ecology 12: 201-212. https://doi.org/10.1111/j.1600-0587.1989.tb00839.x

Received August 28, 2014, accepted February 1, 2017, published July 21, 2017 